\title{
1 Visible ozone-like injury, defoliation, and mortality in two Pinus uncinata stands in the Catalan Pyrenees (NE Spain)
}

3 Maria Díaz-de-Quijano, ${ }^{1,2,}$, Shawn Kefauver ${ }^{2}$, Romà Ogaya ${ }^{2}$, Pierre Vollenweider $^{3}$, Àngela Ribas ${ }^{2}$, Josep Peñuelas ${ }^{1,2}$

$5 \quad$ 'CSIC,Global Ecology Unit CREAF-CEAB-UAB, Cerdanyola del Vallès 08193, Catalonia, Spain.

$6 \quad{ }^{2}$ CREAF, Cerdanyola del Vallès 08193, Catalonia, Spain.

$7 \quad{ }^{3}$ Swiss Federal Institute for Forest, Snow and Landscape Research WSL, Birmensdorf, Switzerland.

8 * Corresponding author. Tel.: +34 9358148 50; fax: +34 935814151 .

9 E-mail address: m.diaz.de.quijano@gmail.com

\section{Abstract}

11 Ozone concentrations in the Pyrenees have exceeded the thresholds for forest protection

12 since 1994 . We surveyed the severity of visible $\mathrm{O}_{3}$ injuries, crown defoliation, and tree

13 mortality of Pinus uncinata, the dominant species in subalpine forests in this mountain

14 range, along two altitudinal and $\mathrm{O}_{3}$ gradients in the central Catalan Pyrenees and 15 analysed their relationships with the local environmental conditions. The severity of 16 visible $\mathrm{O}_{3}$ injuries increased with increasing mean annual $\left[\mathrm{O}_{3}\right]$ when summer water 17 availability was high (summer Precipitation/Potential evapotranspiration above 0.96)

18 whereas higher $\left[\mathrm{O}_{3}\right]$ did not produce more visible injuries during drier conditions. Mean 19 crown defoliation and tree mortality ranged between 20.4-66.4 and 0.6-29.6\%, 20 respectively, depending on the site. Both were positively correlated with the 21 accumulated $\mathrm{O}_{3}$ exposure during the last five years and with variables associated with 22 soil-water availability, which favours greater $\mathrm{O}_{3}$ uptake by increasing stomatal 23 conductance. The results indicate that $\mathrm{O}_{3}$ contributed to the crown defoliation and tree 24 mortality, although further research is clearly warranted to determine the contributions 25 of the multiple stress factors to crown defoliation and mortality in $P$. uncinata stands in 26 the Catalan Pyrenees.

\section{Keywords}

28 Ozone, Pyrenees, Pinus uncinata, visible ozone injury, defoliation, mortality.

\section{Acknowledgements}


31 This research was supported by the European Research Council Synergy grant ERC-

32 2013-SyG-610028 IMBALANCE-P, the Spanish Government grant CGL2013-48074-

33 P, and the Catalan Government grant SGR 2014-274. The first author was funded by a

34 grant from the CSIC JAE programme.

\section{1. Introduction}

37 Ozone $\left(\mathrm{O}_{3}\right)$ concentrations since 1994 in the Catalan Pyrenees have consistently 38 exceeded the critical level $(5000 \mathrm{ppb} \cdot \mathrm{h})$, target value $(9000 \mathrm{ppb} \cdot \mathrm{h})$, and long-term 39 objective $(3000 \mathrm{ppb} \cdot \mathrm{h})$ for the protection of forest and semi-natural vegetation set by the 40 CLRTAP/UNECE and the European Directive 2008/50/EC (Díaz-de-Quijano et al.,

41 2012). An increase of the $\mathrm{O}_{3}$ concentrations by a factor of five $\left(1.6 \% \cdot \mathrm{y}^{-1}\right)$ has been 42 observed in the Pyrenees from the end of the $19^{\text {th }}$ century to the early 1990 s (Marenco et 43 al., 1994). $\mathrm{O}_{3}$ concentrations increased significantly along an altitudinal gradient in the 44 central Catalan Pyrenees, from annual averages of $35 \mathrm{ppb}_{\mathrm{v}}$ at $1040 \mathrm{~m}$ a.s.l. to $56 \mathrm{ppb}_{\mathrm{v}}$ at $452300 \mathrm{~m}$ a.s.l. for 2004-2007, but reaching 38 and $74 \mathrm{ppb}_{\mathrm{v}}$, respectively, during the warm 46 period (April-September) (Diaz-de-Quijano et al., 2009). $\mathrm{O}_{3}$ pollution in the Pyrenees is potentially detrimental to the natural vegetation 48 and forests (Díaz-de-Quijano et al., 2012). High levels of $\mathrm{O}_{3}$ pollution have caused 49 typical $\mathrm{O}_{3}$-induced injuries in studies in other European countries under controlled 50 conditions (Gimeno et al., 2004; Manninen et al., 2003; Marzuoli et al., 2009; Paoletti et 51 al., 2009; Penuelas et al., 1994; Ribas et al., 2005) or in the field (Calatayud et al., 2007; 52 Cvitas et al., 2006; Vollenweider et al., 2003a; Waldner et al., 2007). Some forest trees 53 and herbaceous species along the altitudinal gradient in the Pyrenees are also sensitive 54 to $\mathrm{O}_{3}$, e.g. Fagus sylvatica, Pinus sylvestris, and Betula pendula (Karlsson et al., 2003) 55 and Phleum alpinum, Leontodon hispidus, Valeriana officinalis, Silene acaulis, and 56 Hieracium pilosella (Hayes et al., 2007). $\mathrm{O}_{3}$ detrimental effects on vegetation include 
57 physiological changes in leaves that eventually affect the amount of carbon available for

58 growth and metabolic needs (Andersen, 2003). Since these effects differ among species

59 in quality and magnitude, $\mathrm{O}_{3}$ can alter plant interspecific competition giving place to

60 shifts in community composition and losses of biodiversity (Wedlich et al., 2012).

61 The Mountain Pine (Pinus uncinata Ram.) is an autochthonous European

62 species that dominate the subalpine forests in the central and eastern Pyrenees to 2400

$63 \mathrm{~m}$ a.s.l. from 1600 to 1800 (depending on the area) (Burriel et al., 2004). Mountain pine

64 forests play a key role in the central and eastern Pyrenees regarding timber production

65 (between 190000 and $215000 \mathrm{~m}^{3} /$ year), the protective function against natural risks

66 (floods, avalanches and erosion), biodiversity and landscape conservation, protection of

67 threaten species (i.e. Tetrao urogallus), recreational uses and summer pastures (Coll et

68 al., 2012). Nonetheless, the forest capacity to deliver these ecosystem services can be

69 altered due to changes in their ecological function resulting from global change

70 disturbances (Millar and Stephenson, 2015). The impacts of $\mathrm{O}_{3}$ on these subalpine

71 forests of $P$. uncinata in the Pyrenees and on the livelihoods of forest-dependent

72 communities could have thus major ecological, economic, and social consequences.

73 The effects of $\mathrm{O}_{3}$ on $P$. uncinata have been recently determined in several

74 studies. Two-years old or older foliage of $P$. uncinata can develop diffuse light-green

75 mottling characteristic of $\mathrm{O}_{3}$ stress (Diaz-de-Quijano et al., 2011), similar to that

76 reported in other pine species (Sanz and Calatayud, 2015). This diagnosis was

77 confirmed experimentally (Diaz-de-Quijano et al., 2012b; Mortensen, 1994) and

78 microscopically (Diaz-de-Quijano et al., 2011), with typical hypersensitive-like

79 reactions underlying and causing the visible injury (Günthardt-Goerg and Vollenweider,

80 2007; Vollenweider et al., 2013). However, the extent of visible $\mathrm{O}_{3}$ injuries to $P$. 
81 uncinata stands in the Pyrenees and the general health of this tree species have not yet

82 been determined.

83 The aims of this study were: 1) to evaluate the severity of visible $\mathrm{O}_{3}$ injuries in

84 two $P$. uncinata stands along an altitudinal gradient in the Pyrenees where $\mathrm{O}_{3}$

85 concentrations have been monitored for several years, and 2) to assess crown defoliation

86 and mortality as indicators of the health of the stands.

88 2. Materials and methods

89 2.1. Study area

90 The study area was in the county of La Cerdanya in the central Catalan Pyrenees (north-

91 eastern Spain) (Fig. 1). This region is characterised by a mean annual temperature of 7.4

$92{ }^{\circ} \mathrm{C}$ and a mean annual rainfall near $895 \mathrm{~mm}$ (climatic data for 1951-1999 from the

93 Climatic Digital Atlas of Catalonia (CDAC)Ninyerola et al., 2000), corresponding to a

$94 \mathrm{Cfb}$ climate of the Köppen-Geiger Classification System, defined as a temperate climate

95 without a dry season (Agencia Estatal de Meteorología (España), 2011). Average

96 monthly meteorological data for the study area for 1951-1999 are shown in Fig. 2.

97 We surveyed visible $\mathrm{O}_{3}$-like injuries, crown defoliation, and tree mortality on 98 altitudinal transects within two forest stands dominated by $P$. uncinata (Diaz-de-

99 Quijano et al., 2009). One transect (Guils transect) had a north-eastern aspect and

100 ranged from 1500 to $2200 \mathrm{~m}$ a.s.1., and the other transect (Meranges transect) had a

101 southern aspect and ranged from 1700 to $2300 \mathrm{~m}$ a.s.l. Nine sites were distributed along

102 both transects and were surveyed for visible $\mathrm{O}_{3}$ injury (Fig. 1). Crown defoliation was

103 surveyed in eighteen plots and tree mortality in sixty plots (the same eighteen plots as

104 before plus forty-two new plots) distributed in six sites at altitudes ranging from 1500 to

$1052200 \mathrm{~m}$ (Fig 1). Each plot was $20 \times 20 \mathrm{~m}$ and was separated by at least $30 \mathrm{~m}$ within 
106 homogenous, similarly oriented, and sloping parts of the stands and showed no signs of

107 recent disturbance or sylvicultural treatment. In most cases, plots for crown defoliation

108 and mortality sampling could not be located in the sites where visible foliar injury was

109 assessed because $\mathrm{O}_{3}$ passive sampling with their coresponding visible foliar injury sites

110 did not always show the set of required characteristics just mentioned above.

\section{2.2. Characterisation of site conditions}

113 Topographic wetness indices were used to characterise spatial soil-moisture conditions

114 at a catchment scale (Beven and Kirkby, 1979; O’Loughlin, 1986). These indices

115 assume that topography plays a key role in controlling and modifying the hydrology at a

116 hillslope scale (Grayson et al., 1999). We thus obtained a GIS-derived topographic

117 index (topographic wetness index, TWI) that accounts for the contributing area of the

118 catchment that drains into a given point and for the slope of the terrain, following the

119 method by Galiano et al.(2010). The water availability during summer was estimated by

120 the ratio of summer (July to September) total precipitation to average potential

121 evapotranspiration (P/PET) for 1951-1999.

122 Soil depth was estimated by forcing a $130 \mathrm{~cm}$ steel rod into the soil to the

123 bedrock and averaging readings from five locations. Estimates were obtained at the nine

124 sites where visible $\mathrm{O}_{3}$ injuries were assessed and at the plots used for the assessments of

125 crown defoliation and tree mortality. Maximum water-holding capacity (MWHC) of the

126 soil was estimated by dividing the mass of water retained after $24 \mathrm{~h}$ in a soil core to a

127 depth of $20 \mathrm{~cm}$ by the dry mass of the soil.

128 We used passively sampled $\mathrm{O}_{3}$ concentrations monitored at nine sites (Fig. 1)

129 between 2004 and 2008 to calculate the derived $\mathrm{O}_{3}$ variables. Five sites were located in

130 the Guils transect (north-eastern aspect from 1500 to $2200 \mathrm{~m}$ a.s.l.) and four sites, in the 
131 Meranges transect (southern aspect from 1700 to $2300 \mathrm{~m}$ a.s.1.). The sampling sites

132 were located every $200 \mathrm{~m}$ in altitude in a forested area dominated by Pinus uncinata and

133 in relatively accessible sites to facilitate fortnightly sampling(for further details about

134 the sampling locations and procedure see Diaz-de-Quijano et al., 2009). Radiello radial

135 symmetry passive samplers (Cocheo et al., 1996) were used to analyse $\mathrm{O}_{3}$ at all

136 sampling sites. Frequency of sampling was two weeks during the warm period (April to

137 September) and once a month in the cold period (October to March). The derived $\mathrm{O}_{3}$

138 variables comprised the average of the mean annual concentrations for 2005-2007, the

139 average of the mean summer (April to September) concentrations for 2004-2008, and

140 the accumulated sum of the mean fortnightly concentrations for 2004-2008. The average

141 mean annual $\mathrm{O}_{3}$ concentrations for 2005-2007 were selected for comparison with the

$142 \mathrm{O}_{3}$-induced injuries on the basis of previously identified correlations between these two

143 estimates (Kefauver et al., 2014). We used the sum of mean fortnightly $\mathrm{O}_{3}$

144 concentrations for 2004-2008 for comparison with estimates of crown defoliation and

145 tree mortality. The mean $\mathrm{O}_{3}$ concentrations from April to September for 2004-2008 were

146 calculated in order to better characterize each site .

148 2.3. Assessment of the severity of visible $\mathrm{O}_{3}$ injury

149 A total of 27 P. uncinata trees were examined for visible $\mathrm{O}_{3}$ injury in May 2007. Three

150 trees 1) close to the measuring station, 2) at least $2 \mathrm{~m}$ high, 3) with a diameter at breast

151 height $(\mathrm{DBH})>10 \mathrm{~cm}$, and 4) with accessible and unshaded branches were selected at

152 each of the nine sites equipped with $\mathrm{O}_{3}$ passive samplers (Fig. 1; Díaz-de-Quijano et al., 153 2009). Outer and non-terminal branches with a minimum of five needle generations 154 were sampled from the northern and southern sides of the trees at mid-canopy height 155 and from the tree tops using a tree-pruning pole. The severity of visible $\mathrm{O}_{3}$ injury (VI- 
$156 \mathrm{sev}$ ) is one of the two scaled scorings of visual chlorotic mottling (VI), which is part of

157 the Ozone Injury Index (OII) (Arbaugh et al., 1998; Duriscoe et al., 1996 and see

158 http://www.fs.fed.us/psw/publications/documents/gtr-155/ for further details). VI-sev is

159 calculated by estimating the average percentage of chlorotic mottling for all

160 symptomatic needles and converting the estimates into a semi-quantitative variable with

161 five grades of intensity (1:1-6, 2:7-25, 3:26-50, 4:51-75, and 5:>75\%). A computer-

162 generated chart with different percentage covers of chlorotic mottling was used to assess

163 the VI-sev in order to reduce the source of personal error.

165 2.4. Assessment of crown defoliation and tree mortality

166 Crown defoliation and tree mortality were assessed in July 2008. Crown defoliation

167 was estimated by a method slightly modified from that described in the

168 UNECE/CLRTAP manual (UNECE/CLRTAP, 2006). We chose four subplots oriented

169 along the main compass directions $8 \mathrm{~m}$ from the centre of each plot. The six trees

170 nearest to the subplot centre were selected as sample trees, for a total of 24 sample trees

171 per plot. Defoliation was estimated in $5 \%$ classes relative to a reference tree as

172 suggested in the manual (UNECE/CLRTAP, 2006). The reference tree was a healthy

173 tree with no defoliation, located in the lowest altitude site of the Meranges transect. It

174 was representative of approximately $75 \%$ of the trees in this site. Ratings were averaged

175 at the plot level. Tree mortality was assessed by counting the total numbers of live and

176 dead trees and measuring the $\mathrm{DBH}$ of each tree. The tree density, percentage of dead

177 trees, and total basal area (BA) were then calculated and averaged at the plot level. 
180 General linear models were used to study the relationships between site characteristics

181 and severity of visible injury, defoliation, and mortality. Parameters of the fitted models

182 ( $\beta$ ) were estimated using maximum likelihood. The selection of the model was based on

183 a stepwise procedure using the Akaike information criterion (AIC). Data were

184 transformed when needed to satisfy the assumption of normality (log(VI-sev),

$185 \log ($ defoliation $), \log ($ mortality+1)). All analyses were performed with $\mathrm{R}$, version 2.12 .2

186 (2011, The R Foundation for Statistical Computing).

\section{3. Results}

\section{3.1. Assessment of severity of visible $\mathrm{O}_{3}$ injury}

190 VI-sev ranged between 1 and 2 on the Guils transect and 1.4 and 3.2 on the Meranges

191 transect (Table 1). VI-sev was higher in sites at higher altitude (Table 1) on both 192 transects, but the average VI-sev was lower on the Guils (mean \pm SE of $1.26 \pm 0.2$ ) than

193 the Meranges (mean \pm SE of $2.08 \pm 0.4$ ) transect. The final model for VI-sev fitted using 194 stepwise model selection is shown in Table 2. The interactions between the explanatory 195 variables in the model were significant. A higher VI-sev was thus associated with 196 higher $\left[\mathrm{O}_{3}\right]$ only when summer P/PET was >0.96. Individual relationships of VI-sev 197 with summer P/PET and mean annual $\left[\mathrm{O}_{3}\right]$ for 2005-2007 are shown in Fig. 3.

\section{3.2. Defoliation and tree mortality}

200 A summary of the defoliation and tree mortality grouped by altitude are shown in Table

201 3. Defoliation ranged between 20 and $66 \%$ and was generally higher on the Guils than 202 the Meranges transect. Defoliation and tree mortality also clearly tended to increase 203 with altitude on the Guils transect (Table 3). This pattern was not as clear on the 204 Meranges transect, where the mid-altitude site had the highest defoliation. Tree 
205 mortality increased with altitude on both transects but was higher on the Guils transect,

206 ranging between $1-30$ and $1-7.5 \%$ on the Guils and Meranges transects, respectively.

207 The Guils transect generally had clearer increasing trends with altitude and higher

208 defoliation and mortality than the Meranges transect (Table 3). The Guils transect also

209 had wetter conditions than Meranges, as indicated by the generally higher values for the

210 variables associated with site water availability (e.g. topographic wetness index, soil

211 depth, MWHC) (Table 3).

212 Both defoliation and mortality were mostly affected by the sum of the mean

213 fortnightly $\left[\mathrm{O}_{3}\right]$ for $2004-2008$ but were also associated with the explanatory variables

214 defining site water availability and stand characteristics (Table 2). Increases in

215 defoliation and mortality were associated with higher accumulated exposures to $\mathrm{O}_{3}$ and

216 with higher water availability, which was represented by MWHC for defoliation and by

217 the topographic wetness index and summer P/PET for mortality (Figs. 4 and 5). Both

218 defoliation and mortality showed the highest values above a threshold of sum of

219 fortnightly $\left[\mathrm{O}_{3}\right]$ of $2900 \mathrm{ppb}$. Defoliation increased abruptly above an MWHC threshold

220 of $0.58 \mathrm{~g} \mathrm{H}_{2} \mathrm{O} \cdot \mathrm{g}$ soil $^{-1}$, and mortality increased above a threshold of 12.5 of the

221 topographic wetness index. Stand basal area was negatively correlated with defoliation

222 in the defoliation model, although only marginally, whereas mean DBH was positively

223 correlated with mortality.

225 4. Discussion

226 4.1. Dependence of VI-sev on summer P/PET and mean annual [O ${ }_{3}$ for 2005-2007

227 The effects of $\mathrm{O}_{3}$ on vegetation depend on the amount of $\mathrm{O}_{3}$ entering the leaves and the 228 plant's sensitivity to $\mathrm{O}_{3}$ (Matyssek et al., 2008). $\mathrm{O}_{3}$ uptake is highly influenced by the 
229 availability of soil moisture, because it directly affects stomatal conductance (Nunn et

230 al., 2005; Patterson et al., 2000; Schaub et al., 2007, 2003). Soil-water availability may

231 also be one of the most important site factors influencing the response of trees to $\mathrm{O}_{3}$

232 stress (Lefohn et al., 1997; Ollinger et al., 1997; Vollenweider et al., 2003a, 2003b).

233 This influence is in agreement with our results showing that the severity of visible $\mathrm{O}_{3}$

234 injury increased with increasing $\left[\mathrm{O}_{3}\right]$ under situations of relatively high summer P/PET

235 (>0.96). Stomatal conductance, and the consequent $\mathrm{O}_{3}$ uptake, were likely high under

236 high summer P/PET. The lower VI-sev with increasing $\left[\mathrm{O}_{3}\right]$ under conditions of low

237 summer P/PET could similarly be due to lower stomatal conductances under a certain

238 level of water availability. Under a situation of low water availability, $\mathrm{O}_{3}$ uptake will

239 remain low and cause fewer injuries even if atmospheric $\left[\mathrm{O}_{3}\right]$ is high.

240 Visible $\mathrm{O}_{3}$ injury could thus be much better predicted using a stomatal flux-

241 based model that includes the factors influencing stomatal conductance and the specific

242 hourly $\left[\mathrm{O}_{3}\right]$ at each site. More effort should thus focus on characterising the hourly $\left[\mathrm{O}_{3}\right]$

243 at each site and the micro-environmental conditions that affect stomatal conductance,

244 which are usually influenced by local topography and stand structure. This would

245 certainly permit to better analyse the relationship between visible $\mathrm{O}_{3}$ injury and the

246 specific environmental conditions at each site. The mean percentage of the area of all

247 symptomatic needles with chlorotic mottling at each site was $\leq 30 \%$ (VI-sev score of

248 3.22), but visible injury could have appeared much later than below-ground responses to

$249 \mathrm{O}_{3}$, and negative effects on a cellular and histological level may have already begun

250 (Andersen, 2003; Laurence and Andersen, 2003).

252 4.2. Higher crown defoliation and tree mortality associated with higher accumulated $\mathrm{O}_{3}$ 253 exposure and water availability 
254 The mean values of crown defoliation between 20 and $66 \%$ at our study sites were not

255 surprising, because the defoliation of $P$. uncinata crowns increased in the Iberian

256 Peninsula from 15 to $25 \%$ between 1996 and 2006 (Carnicer et al., 2011). The rate of

257 mortality followed the same pattern as defoliation, being higher at those sites with

258 higher defoliation. The average mortality rate for all sites was $9.19 \%$, which is similar

259 to the $6 \%$ for $1997-2007$ for the same species throughout the Iberian Peninsula

260 (Carnicer et al., 2011). In fact, several studies have reported significant correlations

261 between deteriorating crown conditions and tree mortality (Dobbertin and Brang, 2001;

262 Drobyshev et al., 2007; Eckmullner and Sterba, 2000). The high crown defoliation and

263 tree mortality, with defoliation $>25 \%$ considered to be indicative of poor tree health

264 (Innes, 1998), show that the stands of $P$. uncinata in our study generally had poor

265 vitality.

266 Crown defoliation and tree mortality were correlated most with the accumulated

$267 \mathrm{O}_{3}$ exposure during the last five years and with variables characterising soil-water

268 availability. Plant responses to $\mathrm{O}_{3}$ depend on the amount of $\mathrm{O}_{3}$ entering the leaves and

269 the plant's sensitivity to $\mathrm{O}_{3}$ (Matyssek et al., 2008). The amount of $\mathrm{O}_{3}$ entering the

270 leaves is mainly affected by the atmospheric $\mathrm{O}_{3}$ concentration and by the stomatal

271 conductance (Ro-Poulsen et al., 1998), which is controlled by a range of environmental

272 variables such as light intensity, temperature, vapour-pressure deficit, and soil-water

273 availability (Zierl, 2002). Soil-water availability subsequently affects $\mathrm{O}_{3}$ uptake by

274 plants (Nunn et al., 2005; Panek and Goldstein, 2001; Patterson et al., 2000; Schaub et

275 al., 2007, 2003). The higher defoliation and mortality at our sites with higher soil-water

276 availabilities and accumulated $\mathrm{O}_{3}$ exposures could thus be due to higher uptakes of $\mathrm{O}_{3}$.

277 In effect, the Guils transect, which was significantly wetter than the Meranges transect,

278 had the most crown defoliation and tree mortality. 
We could not, however, identify $\mathrm{O}_{3}$ exposure as the main causing factor of

280 crown defoliation and subsequent tree mortality. Crown assessment based on crown

281 defoliation is one of the best indicators of tree vitality (Dobbertin, 2005), but tree

282 vitality is influenced by a multitude of stress factors (meteorological (e.g. air

283 temperature and frost), hydrological (e.g. droughts and floods), biological (e.g. fungal

284 disease and insects), chemical (e.g. air or soil pollution and soil nutrients), and physical

285 (e.g. wind)) (Aamlid et al., 2000; De Vries et al., 2000; Landmann and Bonneau, 1995;

286 Wellbum, 1994; Zierl, 2002). Hence, $\mathrm{O}_{3}$ exposure cannot be established as the main

287 cause of crown defoliation and tree mortality in our study: a multitude of other

288 environmental or anthropogenic stresses difficult to detect and quantify could also be

289 contributing to the poor tree vitality. Further research should be thus conducted in order

290 to determine the contribution of other stress factors as well as to diminish the sources of

291 uncertainty. Hourly measurements of $\left[\mathrm{O}_{3}\right]$ at each site would supply more precise data

292 on $\mathrm{O}_{3}$ exposure than sum of mean fortnightly $\left[\mathrm{O}_{3}\right]$. The use of this kind of data would

293 diminish the uncertainties entailed by the use of mean fortnightly $\left[\mathrm{O}_{3}\right]$ measured by

294 passive sampling and it could probably help to better disentangle the relationship

295 between tree vitality and $\mathrm{O}_{3}$ exposure.

\section{5. Conclusions}

298 This study on the severity of visible $\mathrm{O}_{3}$ injury, crown defoliation, and tree mortality 299 along two altitudinal and $\mathrm{O}_{3}$ gradients in stands of $P$. uncinata in the Catalan Pyrenees 300 indicates that $\mathrm{O}_{3}$ contributes in part to the reduced tree vitality in this region. The 301 severity of visible $\mathrm{O}_{3}$ injuries increased with mean annual $\left[\mathrm{O}_{3}\right]$ when summer P/PET 302 was above a threshold of 0.96 , whereas higher $\left[\mathrm{O}_{3}\right]$ in drier conditions did not cause 303 more visible $\mathrm{O}_{3}$ injury. Crown defoliation and tree mortality were positively correlated 
304 with the accumulated $\mathrm{O}_{3}$ exposure during the last five years and with variables

305 associated with soil-water availability, which suggests a likely higher uptake of $\mathrm{O}_{3}$,

306 because soil-water availability highly influences stomatal conductance. The effect of $\mathrm{O}_{3}$

307 could not, however, be established conclusively and definitively as the main cause of

308 the crown defoliation and tree mortality in our study, because a multitude of other stress

309 factors could also be contributing to the poor tree vitality. We can nonetheless conclude

310 that $\mathrm{O}_{3}$ is probably one of the factors involved in the crown defoliation and tree

311 mortality in this area, although further research is clearly warranted to determine the

312 contributions of the various other stress factors.

\section{References}

315 Aamlid, D., Torseth, K., Venn, K., Stuanes, A.O., Solberg, S., Hylen, G.,

316 Christophersen, N., Framstad, E., 2000. Changes of forest health in Norwegian boreal 317 forests during 15 years. For. Ecol. Manag. 127, 103-118.

Agencia Estatal de Meteorología (España), 2011. Atlas climático ibérico: temperatura del aire y precipitación $(1971-2000)=$ Atlas climático ibérico : temperatura do ar e precipitação (1971-2000) = Iberian climate atlas : air temperature. Instituto Nacional de Meteorología, Madrid.

Andersen, C.P., 2003. Source-sink balance and carbon allocation below ground in plants exposed to ozone. New Phytol. 157, 213-228.

Arbaugh, M.J., Miller, P.R., Carroll, J.J., Takemoto, B., Procter, T., 1998. Relationships of ozone exposure to pine injury in the Sierra Nevada and San Bernardino Mountains of

Beven, K., Kirkby, M.J., 1979. A physically based variable contributing area model of basin hydrology. Hydrol. Sci. Bull. 24, 43-69.

Burriel, J.A., Gràcia, C., Ibanez, J.J., 2004. Inventari Ecologic i Forestal de Catalunya. (Report). CREAF.

Calatayud, V., Sanz, M.J., Calvo, E., Cervero, J., Ansel, W., Klumpp, A., 2007. Ozone biomonitoring with Bel-W3 tobacco plants in the city of Valencia (Spain). Water. Air. Soil Pollut. 183, 283-291. 
Cocheo, V., Boaretto, C., Sacco, P., 1996. High uptake rate radial diffusive sampler suitable for both solvent and thermal desorption. Am. Ind. Hyg. Assoc. J. 57, 897-904.

Coll, L., Martin, S., Nouguier, S., Ladier, J., Decoux, J.-L., Valadon, A., Cantegrel, R., Sivade, L., 2012. Guide de sylviculture du pin à crochets dans les Pyrénées (Projet POCTEFA - "La gestion des peuplements et la valorisation du bois de pins à crochets" No. EFA82/08 UNCI'PLUS). Centre Tecnologic Forestal de Catalunya, Office National des Forêts, Parc Natural Régional des Pyrénnées Catalanes.

Cvitas, T., Kezele, N., Klasinc, L., Sorgo, G., 2006. AOT40 as preliminary indicator for ozone induced forest injury on Mountain Medvednica near Zagreb. Period. Biol. 108, 639-641.

De Vries, W., Klap, J.M., Erisman, J.W., 2000. Effects of environmental stress on forest crown condition in Europe. Part I: Hypotheses and approach to the study. Water. Air.

Diaz-de-Quijano, M., Penuelas, J., Menard, T., Vollenweider, P., 2011. Visible and microscopical ozone injury in mountain pine (Pinus mugo subsp. uncinata) foliage from the Catalan Pyrenees. Presented at the International Conference Ozone, climate change and forests, Prague, Czech Republic.

Diaz-de-Quijano, M., Penuelas, J., Ribas, A., 2012a. Trends of AOT40 at three sites in the Catalan Pyrenees over the last 16 years. J. Atmospheric Chem. DOI $10.1007 / \mathrm{s} 10874-012-9222-9$.

Diaz-de-Quijano, M., Peñuelas, J., Ribas, À., 2009. Increasing interannual and altitudinal ozone mixing ratios in the Catalan Pyrenees. Atmos. Environ. 43, 60496057. doi:10.1016/j.atmosenv.2009.08.035

Diaz-de-Quijano, M., Schaub, M., Bassin, S., Volk, M., Peñuelas, J., 2012b. Ozone visible symptoms and reduced root biomass in the subalpine species Pinus uncinata after two years of free-air ozone fumigation. Environ. Pollut., Interactions Between Indoor and Outdoor Air Pollution - Trends and Scientific Challenges Ozone, Climate Change and Forests 169, 250-257. doi:10.1016/j.envpol.2012.02.011

Dobbertin, M., 2005. Tree growth as indicator of tree vitality and of tree reaction to environmental stress: a review. Eur. J. For. Res. 124, 319-333.

Dobbertin, M., Brang, P., 2001. Crown defoliation improves tree mortality models. For. Ecol. Manag. 141, 271-284.

Drobyshev, I., Linderson, H., Sonesson, K., 2007. Relationship between crown condition and tree diameter growth in southern Swedish oaks. Environ. Monit. Assess. $128,61-73$.

Duriscoe, D., Stolte, K., Pronos, J., 1996. History of ozone injury monitoring methods and the development of a recommended protocol (Report No. Gen. Tech. Rep. PSW- 

Agriculture.

Eckmullner, O., Sterba, H., 2000. Crown condition, needle mass, and sapwood area relationships of Norway spruce (Picea abies). Can. J. For. Res.-Rev. Can. Rech. For. 30, $1646-1654$.

Galiano, L., Martinez-Vilalta, J., Lloret, F., 2010. Drought-Induced Multifactor Decline of Scots Pine in the Pyrenees and Potential Vegetation Change by the Expansion of Cooccurring Oak Species. Ecosystems 13, 978-991.

Gimeno, B.S., Bermejo, V., Sanz, J., la Torre, D. de, Elvira, S., 2004. Growth response to ozone of annual species from Mediterranean pastures. Environ. Pollut. 132, 297-306.

Grayson, R., Western, A., Wilson, D., Young, R., McMahon, T., Woods, R., Duncan, M., BlÃAlschl, G., 1999. Measurements and interpretation of soil moisture for hydrological applications, in: Water 99: Joint Congress. pp. 5-9.

Günthardt-Goerg, M.S., Vollenweider, P., 2007. Linking stress with macroscopic and microscopic leaf response in trees: New diagnostic perspectives. Environ. Pollut. 147, 467-488.

Hayes, F., Jones, M.L.M., Mills, G., Ashmore, M., 2007. Meta-analysis of the relative sensitivity of semi-natural vegetation species to ozone. Environ. Pollut. 146, 754-762.

Innes, J.L., 1998. An assessment of the use of crown structure for the determination of the health of beech (Fagus sylvatica). Forestry 71, 113-130.

Karlsson, P.E., Uddling, J., Braum, S., Broadmeadow, M., Elvira, S., Sanchez-Gimeno, G., Le Thiec, D., Oksanen, E., Vandermeiren, K., Wilkinson, M., Emberson, L., 2003. New critical levels for ozone impact on trees based on AOT40 and leaf cumulated uptake of ozone, in: Kalsson, P.E., Selldén, G., Pleijel, H. (Eds.), Establishing Ozone Critical Levels. IVL Swedish Environmental Research Institute, Gothenburg, pp. 236250 .

Kefauver, S.C., Peñuelas, J., Ribas, A., Diaz-de-Quijano, M., Ustin, S., 2014. Using Pinus uncinata to monitor tropospheric ozone in the Pyrenees. Ecol. Indic. 36, 262-271. doi:10.1016/j.ecolind.2013.07.024

Landmann, G., Bonneau, M., 1995. Forest decline and atmospheric deposition effects in the French mountains. Springer.

Laurence, J.A., Andersen, C.P., 2003. Ozone and natural systems: understanding exposure, response and risk. Environ. Int. 29, 155-160.

Lefohn, A.S., Jackson, W., Shadwick, D.S., Knudsen, H.P., 1997. Effect of surface ozone exposures on vegetation grown in the Southern Appalachian Mountains: Identification of possible areas of concern. Atmos. Environ. 31, 1695-1708.

Manninen, S., Sorjamaa, R., Kurki, S., Pirttiniemi, N., Huttunen, S., 2003. Ozone 
affects Scots pine phenology and growth, in: Air Pollution, Global Change and Forests in the New Millennium, Developments in Environmental Science. pp. 231-246.

Marenco, A., Gouget, H., Nedelec, P., Pages, J.P., Karcher, F., 1994. Evidence of a Long-Term Increase in Tropospheric Ozone from Pic Du Midi Data Series Consequences - Positive Radiative Forcing. J. Geophys. Res.-Atmospheres 99, 1661716632.

Marzuoli, R., Gerosa, G., Desotgiu, R., Bussotti, F., Ballarin-Denti, A., 2009. Ozone fluxes and foliar injury development in the ozone-sensitive poplar clone Oxford (Populus maximowiczii x Populus berolinensis): a dose-response analysis. Tree Physiol. 29, 67-76.

Matyssek, R., Sandermann, H., Wieser, G., Booker, F., Cieslik, S., Musselman, R., Ernst, D., 2008. The challenge of making ozone risk assessment for forest trees more mechanistic. Environ. Pollut. 156, 567-582.

Millar, C.I., Stephenson, N.L., 2015. Temperate forest health in an era of emerging megadisturbance. Science 349, 823-826. doi:10.1126/science.aaa9933

Mortensen, L.M., 1994. The influence of carbon dioxide or ozone concentration on growth and assimilate partitioning in seedlings of nine conifers. Acta Agric. Scand. Sect. B Soil Plant Sci. 44, 157-163.

Ninyerola, M., Pons, X., Roure, J.M., 2000. A methodological approach of climatological modelling of air temperature and precipitation through GIS techniques. Int. J. Climatol. 20, 1823-1841. doi:10.1002/1097-0088(20001130)20:14<1823::AIDJOC566>3.0.CO;2-B

Nunn, A.J., Kozovits, A.R., Reiter, I.M., Heerdt, C., Leuchner, M., Luetz, C., Liu, X., Loew, M., Winkler, J.B., Grams, T.E.E., Haeberle, K.H., Werner, H., Fabian, P., Rennenberg, H., Matyssek, R., 2005. Comparison of ozone uptake and sensitivity between a phytotron study with young beech and a field experiment with adult beech (Fagus sylvatica). Environ. Pollut. 137, 494-506.

Ollinger, S.V., Aber, J.D., Reich, P.B., 1997. Simulating ozone effects on forest productivity: Interactions among leaf-, canopy-, and stand-level processes. Ecol. Appl. 7, 1237-1251.

O'Loughlin, E.M., 1986. Predictions of surface saturation zones in natural catchments by topographic analysis. Water Resour. Res. 22, 794-804.

Panek, J.A., Goldstein, A.H., 2001. Response of stomatal conductance to drought in ponderosa pine: implications for carbon and ozone uptake. Tree Physiol. 21, 337-344.

Paoletti, E., Contran, N., Bernasconi, P., Günthardt-Goerg, M.S., Vollenweider, P., 2009. Structural and physiological responses to ozone in Manna ash (Fraxinus ornus L.) leaves of seedlings and mature trees under controlled and ambient conditions. Sci. Total Environ. 407, 1631-1643. doi:10.1016/j.scitotenv.2008.11.061 
Patterson, M.C., Samuelson, L., Somers, G., Mays, A., 2000. Environmental control of stomatal conductance in forest trees of the Great Smoky Mountains National Park. Environ. Pollut. 110, 225-233.

Peñuelas, J., Ribas-Carbo, M., Gonzalez-Meler, M., Azcon-Bieto, J., 1994. Water status, photosynthetic pigments, $\mathrm{C} / \mathrm{N}$ ratios and respiration rates of stika spruce seedlings exposed to 70 ppbv ozone for a summer. Environ. Exp. Bot. 34, 443-449.

Ribas, Ã., Peñuelas, J., Elvira, S., Gimeno, B.S., 2005. Ozone exposure induces the activation of leaf senescence-related processes and morphological and growth changes

Ro-Poulsen, H., Mikkelsen, T.N., Hovmand, M.F., Hummelsehoj, P., Jensen, N.O., 1998. Ozone deposition in relation to canopy physiology in a mixed conifer forest in Denmark. Chemosphere 36, 669-674.

Sanz, M.J., Calatayud, V., 2015. Ozone Injury in European Forest Species [WWW Document]. URL http://www.ozoneinjury.org. (accessed 2.23.15).

Schaub, M., Emberson, L., Büker, P., Kräuchi, N., 2007. Preliminary results of modeled ozone uptake for Fagus sylvatica L. trees at selected EU/UN-ECE intensive monitoring plots. Environ. Pollut. 145, 636-643.

Schaub, M., Skelly, J.M., Steiner, K.C., Davis, D.D., Pennypacker, S.P., Zhang, J., Ferdinand, J.A., Savage, J.E., Stevenson, R.E., 2003. Physiological and foliar injury responses of Prunus serotina, Fraxinus americana, and Acer rubrum seedlings to varying soil moisture and ozone. Environ. Pollut. 124, 307-320.

UNECE/CLRTAP, 2006. Manual on methods and criteria for harmonized sampling, assessment, monitoring and analysis of the effects of air pollution on forests. Part II: Visual assessment of crown condition. International Co-operative Programme on Assessment and Monitoring of Air Pollution Effects on Forests. http://icp-forests.net/.

Vollenweider, P., Fenn, M.E., Menard, T., Günthardt-Goerg, M., Bytnerowicz, A., 2013. Structural injury underlying mottling in ponderosa pine needles exposed to ambient ozone concentrations in the San Bernardino Mountains near Los Angeles, California. Trees 27, 895-911. doi:10.1007/s00468-013-0843-7

Vollenweider, P., Ottiger, M., Gunthardt-Goerg, M.S., 2003a. Validation of leaf ozone symptoms in natural vegetation using microscopical methods. Environ. Pollut. 124, 101-118.

Vollenweider, P., Woodcock, H., Kelty, M.J., Hofer, R., 2003b. Reduction of stem growth and site dependency of leaf injury in Massachusetts black cherries exhibiting ozone symptoms. Environ. Pollut. 125, 467-480. doi:10.1016/S0269-7491(03)00079-4

Waldner, P., Schaub, M., Pannatier, E.G., Schmitt, M., Thimonier, A., Walthert, L., 2007. Atmospheric deposition and ozone levels in Swiss forests: Are critical values exceeded? Environ. Monit. Assess. 128, 5-17. 
544 Wedlich, K.V., Rintoul, N., Peacock, S., Cape, J.N., Coyle, M., Toet, S., Barnes, J., 545 Ashmore, M., 2012. Effects of ozone on species composition in an upland grassland. 546 Oecologia 168, 1137-1146. doi:10.1007/s00442-011-2154-2

548 Wellbum, A., 1994. Air Pollution and Climate Change, The Biological Impact. 549 Longman Scientific and Technical, Essex, England.

551 Zierl, B., 2002. Relations between crown condition and ozone and its dependence on 552 environmental factors. Environ. Pollut. 119, 55-68. 
errors of the means.

\begin{tabular}{|c|c|c|c|c|c|c|c|c|c|c|c|}
\hline Sites & Latitude & Longitude & $\begin{array}{l}\text { Altitude } \\
\text { (m a.s.l) }\end{array}$ & Aspect & $\begin{array}{l}\text { Slo } \\
\text { pe } \\
(\stackrel{\circ}{)})\end{array}$ & $\begin{array}{c}\text { Topographic } \\
\text { Wetness Index }\end{array}$ & $\begin{array}{l}\text { Summer } \\
\text { P/PET }\end{array}$ & $\begin{array}{l}\text { Soil } \\
\text { depth } \\
\text { (cm) }\end{array}$ & $\begin{array}{c}\mathrm{MWHC}(\mathrm{g} \\
\mathrm{H}_{2} \mathrm{O} \cdot \mathrm{g} \text { soil } \\
\text {, }\end{array}$ & $\begin{array}{c}\text { Mean } \\
\text { annual }\left[\mathrm{O}_{3}\right] \\
2005-2007 \\
(\mathrm{ppb})\end{array}$ & $\begin{array}{l}\text { Severity of } \\
\text { visible injury }\end{array}$ \\
\hline \multirow{6}{*}{ 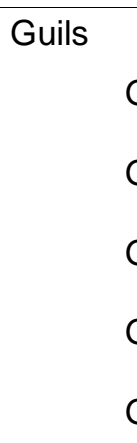 } & & & & & & & & $n=5$ & $n=3$ & & $n=3$ \\
\hline & 42.458532 & 1.877621 & 1500 & NE & 25 & 12.74 & 0.69 & $\begin{array}{c}50.6( \\
6.9)\end{array}$ & $0.312(0.04)$ & 46.1 & $1(0.0)$ \\
\hline & 42.460940 & 1.864956 & 1700 & NE & 15 & 11.58 & 0.76 & $\begin{array}{c}36.4( \\
8.8)\end{array}$ & $0.416(0.01)$ & 47.2 & $1(0.2)$ \\
\hline & 42.458108 & 1.856287 & 1800 & $\mathrm{NE}$ & 15 & 11.37 & 0.85 & $\begin{array}{c}65.8( \\
5.6)\end{array}$ & $0.436(0.08)$ & 53.7 & $1.1(0.3)$ \\
\hline & 42.458333 & 1.842645 & 2000 & NE & 5 & 13.37 & 0.92 & $\begin{array}{c}68.4( \\
3.9)\end{array}$ & $0.635(0.12)$ & 53.9 & $1.2(0.2)$ \\
\hline & 42.462582 & 1.808833 & 2200 & NE & 2 & 11.44 & 1.12 & $\begin{array}{c}56(10 \\
.0)\end{array}$ & $0.662(0.02)$ & 50.9 & $2(0.5)$ \\
\hline \multicolumn{12}{|l|}{ Meranges } \\
\hline M1 & 42.452438 & 1.792290 & 1700 & SW & 42 & 8.42 & 0.91 & $\begin{array}{c}42.6( \\
4.5)\end{array}$ & $0.286(0.04)$ & 46.9 & $1.4(0.3)$ \\
\hline M2 & 42.456236 & 1.789355 & 1900 & SE & 30 & 9.68 & 1.02 & $\begin{array}{c}21.0( \\
0.5)\end{array}$ & $0.467(0.05)$ & 50.8 & $1.5(0.5)$ \\
\hline M4 & 42.464095 & 1.785139 & 2100 & S & 5 & 9.55 & 1.09 & $\begin{array}{c}30.4( \\
3.4)\end{array}$ & $0.644(0.07)$ & 54.7 & $2.1(0.4)$ \\
\hline M6 & 42.465586 & 1.778331 & 2300 & SE & 35 & 9.71 & 1.18 & $\begin{array}{c}42.0( \\
5.2)\end{array}$ & $0.687(0.03)$ & 62.1 & $3.2(0.4)$ \\
\hline
\end{tabular}

557 
558 Table 2. General linear models for severity of visible injury, defoliation, and mortality. The data for the dependent variables were normalised by log 559 transformation.

560

\begin{tabular}{|c|c|c|c|}
\hline Model term & $\beta$ & SE & $p$ \\
\hline \multicolumn{4}{|l|}{ Severity of visible injury (VI-sev) model } \\
\hline Intercept & 19.427 & 5.136 & $<0.05$ \\
\hline Mean annual $\left[\mathrm{O}_{3}\right] 2005-2007$ & -0.418 & 0.105 & $<0.05$ \\
\hline Summer P/PET & -18.769 & 4.619 & $<0.01$ \\
\hline Mean annual $\left[\mathrm{O}_{3}\right] 2005-2007^{\star}$ Summer P/PET & 0.436 & 0.093 & $<0.01$ \\
\hline \multicolumn{4}{|l|}{ Defoliation model } \\
\hline Intercept & -0.486 & 0.772 & 0.538 \\
\hline Sum of mean fortnightly $\left[\mathrm{O}_{3}\right] 2004-2008$ & $6.93 \cdot 10^{-4}$ & $3.06 \cdot 10^{-4}$ & $<0.05$ \\
\hline Basal area & $-4.2 \cdot 10^{-3}$ & $1.98 \cdot 10^{-3}$ & $<0.1$ \\
\hline Maximum water-holding capacity & 0.537 & 0.265 & $<0.1$ \\
\hline \multicolumn{4}{|l|}{ Mortality model } \\
\hline Intercept & -2.110 & 2.317 & $<0.001$ \\
\hline Sum of mean fortnightly $\left[\mathrm{O}_{3}\right] 2004-2008$ & $5.21 \cdot 10^{-3}$ & $9.05 \cdot 10^{-4}$ & $<0.001$ \\
\hline Topographic wetness index & 0.379 & 0.114 & $<0.01$ \\
\hline Summer P/PET & 1.871 & 0.751 & $<0.05$ \\
\hline Mean DBH & 0.095 & 0.047 & $<0.1$ \\
\hline
\end{tabular}

A stepwise model selection was used starting from the set of variables in Table 1 (for the VI-sev model) and Table

3 (for the defoliation and mortality models). Only the final models are shown. AICvi-sev=-16.65, AICdefoliation=-

561

68.95, AICmortality $=-137.66$.

562

563

564

565

566 


\begin{tabular}{|c|c|c|c|c|c|c|c|c|c|c|c|c|}
\hline Sites & $\begin{array}{l}\text { Number } \\
\text { of plots }\end{array}$ & $\begin{array}{l}\text { Altitude (m } \\
\text { a.s.l.) }\end{array}$ & $\begin{array}{c}\text { Topographic } \\
\text { wetness } \\
\text { index }\end{array}$ & $\begin{array}{l}\text { Summer } \\
\text { P/PET }\end{array}$ & $\begin{array}{l}\text { Soil depth } \\
\quad(\mathrm{cm})\end{array}$ & $\begin{array}{c}\text { MWHC }(g \\
\left.\mathrm{H}_{2} \mathrm{O} \cdot \mathrm{g} \mathrm{soil}^{-1}\right)\end{array}$ & $\begin{array}{l}\text { Individuals. } \\
\text { ha }^{-1}\end{array}$ & $\mathrm{DBH}$ & Basal area & $\begin{array}{c}\text { Mean }\left[\mathrm{O}_{3}\right] \\
\text { April- } \\
\text { Setember } \\
2004-2008 \\
\text { (ppb) }\end{array}$ & $\begin{array}{c}\text { Sum of } \\
\text { fortnightly } \\
{\left[\mathrm{O}_{3}\right] 2004-} \\
2008 \\
\text { (ppb) }\end{array}$ & $\begin{array}{c}\text { Defoliation } \\
(\%)\end{array}$ \\
\hline \multicolumn{13}{|l|}{ Guils } \\
\hline G6 & 3 & $2211(1.45)$ & $13.09(0.39)$ & $1.12(0.00)$ & $41.2(14.4)$ & $0.618(0.03)$ & $850(281)$ & $19.4(3.7)$ & $32.2(11.8)$ & 50.9 & 2953 & $66.4(15.8)$ \\
\hline G4 & 3 & $1867(15.0)$ & $11.56(1.50)$ & $0.90(0.02)$ & 63.8(6.5) & $0.381(0.08)$ & 2083(563) & $18.8(4.5)$ & $66.6(21.1)$ & 49.8 & 2919 & $32.4(3.7)$ \\
\hline G1 & 3 & $1535(7.3)$ & $10.64(0.34)$ & $0.72(0.00)$ & $53.7(5.1)$ & $0.312(0.06)$ & 1416(448) & $15.4(1.8)$ & $32.9(4.9)$ & 48.7 & 2886 & $36.8(3.4)$ \\
\hline \multicolumn{13}{|l|}{ Meranges } \\
\hline M5 & 3 & 2231(12.2) & $11.29(0.73)$ & $1.13(0.00)$ & $54.6(22.1)$ & $0.481(0.15)$ & 2191(700) & $18.9(1.3)$ & $67.4(12.6)$ & 56.5 & 2926 & $29.8(8.1)$ \\
\hline M3 & 3 & 1998(1.45) & $10.30(0.72)$ & $0.99(0.01)$ & $45.4(17.2)$ & $0.308(0.00)$ & $2225(651)$ & $14.8(1.5)$ & $44.7(8.0)$ & 51.6 & 2759 & $35.2(11.0)$ \\
\hline M1 & 3 & 1797(3.52) & $10.93(0.78)$ & $0.86(1.49)$ & $39.4(3.6)$ & $0.286(0.07)$ & $1133(14)$ & $18.8(1.2)$ & $37.6(5.4)$ & 47.3 & 2615 & $20.4(5.4)$ \\
\hline & & & & & & & & & & & & Mortality (\%) \\
\hline \multicolumn{13}{|l|}{ Guils } \\
\hline G6 & 10 & 2213(3.88) & $12.92(0.29)$ & $1.12(0.00)$ & $41.2(8.2)$ & $0.618(0.03)$ & $887(453)$ & $19.1(3.0)$ & $33.0(15.3)$ & 50.9 & 2953 & $29.6(15.1)$ \\
\hline G4 & 10 & 1869(30.69) & $11.92(1.05)$ & $0.90(0.02)$ & $63.8(4.6)$ & $0.381(0.08)$ & 1997(599) & $17.9(2.9)$ & $59.5(15.6)$ & 49.8 & 2919 & $15.2(8.6)$ \\
\hline \multicolumn{13}{|l|}{ Meranges } \\
\hline M5 & 10 & $2228(26.88)$ & $11.17(0.60)$ & $1.13(0.00)$ & $54.6(12.7)$ & $0.481(0.15)$ & 2350(585) & $18.5(1.2)$ & $71.1(13.6)$ & 56.5 & 2926 & $7.5(6.0)$ \\
\hline M3 & 10 & $2009(20.83)$ & $10.37(0 ; 60)$ & $0.99(0.01)$ & $45.4(9.9)$ & $0.308(0.00)$ & $2110(364)$ & $15.9(1.2)$ & $50.5(10.1)$ & 51.6 & 2759 & $0.8(1.2)$ \\
\hline M1 & 10 & 1793(19.92) & $11.16(0.71)$ & $0.86(0.00)$ & $39.4(2.0)$ & $0.286(0.07)$ & 1557(887) & $17.5(1.6)$ & $42.3(17.4)$ & 47.3 & 2615 & $0.6(1.9)$ \\
\hline
\end{tabular}

568

Table 3. Mean (standard deviation) values of the variables defining plot conditions distributed along six sites.

571

572

573

574 


\section{Figure captions}

576 Fig. 1. Location of the two transects at La Cerdanya in the Central Catalan Pyrenees of Spain.

577 The sites of assessment of visible ozone injury (VI), crown defoliation (tree icon), tree

578 mortality (tree icon), and $\mathrm{O}_{3}$ concentrations $\left(\mathrm{O}_{3}\right)$ (Diaz-de-Quijano et al., 2009) are indicated.

579 Distribution of the eighteen plots of crown defoliation (three plots per site) and the sixty plots

580 of tree mortality (ten plots per site) are not visible in the figure.

581 Fig. 2. Averaged accumulated rainfall (bars) and mean temperatures (lines) from January to

582 December for 1951-1999 (data from the Climatic Digital Atlas of Catalonia

583 (CDAC)(Ninyerola et al., 2000).

584 Fig. 3. Correlation between the severity of visible injury (VI-sev) and summer P/PET (log VI585 sev $=0.9 *$ P/PET-0.7; $\left.p<0.001 ; R^{2}=0.88\right)$ and mean annual $\left[\mathrm{O}_{3}\right]$ for 2005-2007 $(\log$ VI-sev $=$ $5860.03 *\left(\right.$ mean annual $\left.\left.\left[\mathrm{O}_{3}\right] 2005-2007\right)-1.5 ; p<0.05 ; R^{2}=0.59\right)$. Datapoints represent observations 587 at plots from both the Guils and Meranges transects $(n=9)$.

588 Fig. 4. Correlation between defoliation and MWHC (Defoliation=169.3*MWHC ${ }^{2}$ $\left.58971.7 * \mathrm{MWHC}+35.4 ; p<0.01 ; R^{2}=0.46\right)$ and the sum of mean fortnightly $\left[\mathrm{O}_{3}\right]$ for $2004-2008$ 590 (Defoliation $=0.079 \mathrm{e}^{0.0021 \text { SumOzone }} ; p<0.05 ; R^{2}=0.41$ ). Datapoints represent observations at plots 591 from both the Guils and Meranges transects $(n=18)$.

592 Fig. 5. Correlation between mortality and the topographic wetness index 593 (Mortality=5.5*TWI ${ }^{2}-118.2 * \mathrm{TWI}+640.8 ; p<0.001 ; R^{2}=0.66$ ) and the sum of mean fortnightly $594\left[\mathrm{O}_{3}\right]$ for 2004-2008 (Mortality=5 $10^{-4} * \operatorname{Sum} 0408^{2}-2.8^{*} \operatorname{Sum} 0408+3804.8 ; p<0.001 ; R^{2}=0.46$ ). 595 Datapoints represent observations at plots from both the Guils and Meranges transects $(n=60)$. 